\title{
Regulating Paradise: Is Land Use a Right or a Privilege?*
}

\author{
by David L. Callies**
}

\begin{abstract}
Regulating Paradise: Is Land Use a Right or a Privilege? is the concluding chapter in David L. Callies' recent book, Regulating Paradise: Land Use Controls in Hawaii. The book provides a comprebensive guide through the plethora of plans, laws, and regulations that belp determine land use in Hawaii. The basic elements that underlie each regulatory scbeme, as well as the pbilosophies, purposes, and application of the various land use control systems are thoroughly examined in Regulating Paradise. This last analytical chapter explores the right to use land, the proliferation of plans as law, and vested development rights. Additionally the permit explosion, the competing demands made upon rapidly diminishing agricultural lands, and the pervasive effect of federal land policies in Hawaii are addressed.
\end{abstract}

The totality of land regulation in Hawaii raises an increasingly common philosophical issue: Is the use of land in Hawaii a right or a privilege? The issue is unique neither to Hawaii nor any other state. The United States has been blessed with a surplus of undeveloped land from its inception, and its history is virtually a history of land acquisition and development, throughout the eighteenth, nineteenth and twentieth centuries. Indeed, the plentiful supply of undeveloped land was a critical factor in the population and settlement of the nation. 1

It has been over a hundred years, however, since Frederick Jackson Turner implicitly raised the question: What happens when we run out of new lands to

* Adapted from Regulating Paradise: Land Use Controls in Hawaii, by David L. Callies. (C) 1984 by the University of Hawaii Press.

** Professor of Law, William S. Richardson School of Law, University of Hawaii. A.B., De Pauw University, 1965; J.D., University of Michigan, 1968; L.L.M., Nottingham University (England), 1969.

i A. Strong, land Banking: European Reality, American Prospect 24-36 (1979); B. Hibbard, A History of the Public land Policies (1965). 
settle? ${ }^{2}$ As many parts of the United States became highly developed (urbanized) and uses of land overlapped, the question of competing land uses became critical. Thus, while controls had always been a part of our land management philosophy, they became increasingly prevalent in the mid-twentieth century. ${ }^{3}$ Disputes over whether land use is a right or a privilege characterize much of the thought-provoking literature of the past decade. Some commentators preferred to see the development of land continue as a right of ownership." Others expressed a desire to move toward other Anglo-American systems of land development. In these systems if the right to develop had not yet metamorphosed into a privilege dispensed by government, it at least was subject to special scrutiny as "affected with a public interest." Otherwise the right was paid for outright as a "windfall" to compensate those whose development rights were "wiped out" by public land use control decisions."

In Hawaii, Western land ownership and development patterns commenced during the latter half of the nineteenth and early part of the twentieth centuries. This system evolved into the present pattern of urban land development in the state only in the mid-twentieth century. The plethora of land use regulations at every level of government, however, leads inescapably to the conclusion that Hawaii is fast embracing a "privilege" rather than a "right" theory of land development. It takes but a brief comparison of Hawaii with another islandstate with scarce land resources and rampant urbanization-England-to demonstrate the speed with which such a changeover occurs.

\section{LAND USE DEVELOPMENT IN ENGLAND}

The completion of several land use studies coupled with the physical destruction and turmoil resulting from World War II led England to adopt in 1947 a sweeping land use planning law that abolished the private right to develop land. ${ }^{7}$ Extending to every acre of the British Isles, the law required a landowner

2 F. TURner, The Frontier in AMerican History (1920).

3 F. Bosselman \& D. Caines, The Quiet Revolumon in Land Use Control 1-4 (1972); F. Bosselman, D. Calues, \& J. Banta, The Taking Issue: an analysis of the Constitutional Limits OF LAND USE CONTROL 82-104 (1973).

4 F. Bosselman, D. Cames, \& J. Banta, The Taking issue: an Analysis of the Constitutional Limits of LAND USE CONTROL 124-140 (1973).

- Babcock and Feurer, Land as a Commodity Affected with a Public Interest, 52 WASH. L. Rev. 289 (1977); D. Hagman \& D. Misezynski, Windfalls for Wipeouts: Land Value Capture AND COMPENSATION (1979).

- A virtually Norman-feudal tenure system prevailed under King Kamehameha I, the first monarch to unite the Hawaiian Islands. Even in the early nineteenth century the King was the ultimate owner of all land and his nobles or ali' $i$ "held of " him, and their loyal followers of them. F. Bosselman \& D. Caumes, The Quiet Revolution in Land Use Control 5-7 (1972).

7 Town and Country Planning Act, 41 Halsbury's Statutes 1571 (3d ed. 1971) (originally 
to seek local government permission to undertake any form of land development. Development was broadly defined as the carrying out of building, engineering, mining, or other operation in, on, over, or under land or the making of any material change in the use of any buildings or land. ${ }^{8}$ The same law provided for the drawing up of both general and area-specific development plans which would characterize certain lands as appropriate for development. The owners of such land nonetheless had to seek permission from local government before commencing development. Moreover, a local government could legally deny an application for development even though its own development plans showed the land to be in a development category. ${ }^{9}$ While the same law purported to nationalize or condemn existing development rights by establishing a multimillion dollar fund against which landowners denied development permission could claim, no one in England doubts the law would be valid without such "just" compensation. ${ }^{10}$

\section{COMPARISON TO HAWAII}

The parallels with Hawaii are, up to a point, striking. Though spared the urban destruction of World War II, Hawaii also developed its state land use law after a series of studies and reports, which law also covers every acre of land in Hawaii. ${ }^{11}$ Moreover, each of Hawaii's four counties has local laws that do the. same, and all developable land falls in the jurisdiction of one of these counties. ${ }^{\mathbf{1 2}}$ Therefore, all developable land is subject at least to these two levels-state and local - of control. While there are still areas where the owner of land appropriately classified under the state law and zoned under the county codes for development may build without further ado, they are diminishing rapidly with the overlay of various special permit requirements such as shoreland management,

enacted in 1947); THE BARLOW REPORT: REPORT OF THE ROYAL COMMISSION ON THE DISTRIBUtion of the Industrial Population, CMD. No. 6153 (1940); THE SCOTt Report: Report of the Committee on Land Utilization in RuRal AReas, CmD. No. 6378 (1942); The Uthwatt REPORT: RePORT OF THE EXPERT COMMITTEE ON COMPENSATION AND BETTERMENT. CMD. No. 6386 (1942).

Town and Country Planning Act, 41 Halsbury's Statutes $1571 \$$ 22, 290 (3d ed. 1971).

- D. Heap, AN Outline of Planning Law 88 (1977).

$10 \mathrm{~J}$. Cullingworth, TOWn and Country Planning in England and Wales 15-33, 110 31 (1967). Moreover, the British tax laws levy a development tax on new, permitted development, which, since 1947 , has ranged from $30 \%$ to $100 \%$ of the value of the development "increment" upon land value.

11 Hawaii State Planning Act (Act 100), 1978 Hawaii Sess. Laws 136 (codified at HawAII REV. StaT. ch. 226 (Supp. 1980)).

12 Honolulu, Hawaii, General Plan: City and County of Honolulu (1977); Hilo, Hawaii, County of Hawaii: The General Plan (1971); Lihue, Hawaii, A General Plan for the Island of Kauai (1970); Kahului, Hawaii, Maui County General Plan (1980). 
historic preservation, and design-aesthetics. Unlike England, however, Hawaii has not formally either abolished or nationalized the right to develop land nor has it yet decided whether land development is a private right, subject to regulation for health, safety, and welfare of the people at large, or a privilege, for which a private landowner must seek permission and/or pay. How Hawaii deals with the issues of plans as laws, vested rights, and its plethora of land use controls, against a backdrop of federal and federally mandated land use controls, may well decide the question in the next decade.

\section{The Plan as Law and the Proliferation of Plans}

The linking of plans to development control of land is not, of course, restricted to England. Aside from early standard zoning enabling statutory provisions requiring that zoning be in accordance with a comprehensive plan, fourteen states now require that land use regulations be "consistent with" or "conform to" local land use plans. ${ }^{13}$ Some courts have treated such consistency or conformance requirements so stringently that failure of a city to bring its entire zoning scheme into conformance with a new comprehensive plan voids the zoning law. ${ }^{14}$ These decisions have moved one expert to comment that zoning ordinances are fast becoming mere administrative arms of the comprehensive planning process. ${ }^{16}$

While Hawaii state courts have not gone nearly so far, there is no doubt that, on several levels, plans indeed have the force of law in Hawaii. Moreover, there are a great many land use plans, most of which are linked not only to each other but also to state land regulatory agencies and county ordinances, such as those dealing with zoning and subdivision control. This is particularly relevant in the relationship between the state plan-Act 100-and the county plans and land regulation ordinances.

\section{The CONSISTENCY ReQUiRement}

From 1978 to 1984 , Hawaii's four counties were required to have their general and, if any, development plans conform to Act 100. Even after the 1984 amendments to Act 100 (the State Plan), county general and development plans must "define the overall theme, goals, objectives, policies and priority guidelines

\footnotetext{
${ }^{18}$ Garner and Callies, Planning Law in England and Wales and in the United States, 1 ANGLO-AM. L. REV. 305, 310-11 (1972); Callies, Land Use Controls: Of Enterprise Zones, Takings, Plans and Growth Controls, 14 URB. LAw. 798 (1982).

14 E.g., Fasano v. Board of County Comm'r, 489 Or. 693, 507 P.2d 23 (1973).

16 J. Dimento, The Consistency Doctrine and the Limits of Planning (1980).
} 
contained within this chapter." 16 This, of course, has a more direct effect on land use than is apparent on the face of the requirement, since in at least three of Hawaii's four counties, local land use regulations such as zoning and subdivision codes must conform to, or be consistent with, these county plans. Therefore, by requiring some measure of county plan relationship to the goals, policies, objectives, and priority guidelines of the State Plan, the state, through Act 100 , has essentially made at least prospective land use regulations and changes (rezonings, subdivision approvals) subject to at least a relationship with its overall themes, goals, objectives, and priority guidelines. This is coupled with the Act 100 requirements that state land use management and control agencies like the Land Use Commission (boundary amendments) and Board of Land and Natural Resources (land use in the conservation district) must still conform to Act 100's overall theme, goals, objectives, and policies and use as guidelines the new "priority guidelines." 17 Thus, to the extent that Act 100's provisions provide direction for land use decision-making, arguably all the public regulatory and management aspects of land use in Hawaii are guided by the state through Act 100.

Finally, there is the matter of the ten functional plans and their role as laws. The 1984 revisions to Act 100 manage at least to fulfill a state goal of converting the functional plans to guidance documents. Counties are directed only to "take into consideration" statewide objectives, policies, and programs in the functional plans. ${ }^{18}$ State agencies need only "utilize as guidelines" adopted state functional plans. ${ }^{18}$ It is only to Act 100 that they must continue to conform.

But Act 100 is very general, as it should be. Its land use provisions are more expressions of policy than specific directives for use in particular situations. For specifics, Act 100 directs attention to the aforesaid twelve functional plans, ten of which are now law. ${ }^{20}$ This raises an interesting question as to purpose and content. A cursory reading of the functional plans discloses more specificity than Act 100 itself but not enough to provide a basis for land use decision-making at the county level. Even to the extent that the functional plans are principally refinements to and extensions of Act 100's substantive provisions, there is not the level of detail contemplated at most county development plan levels to guide land use decision-making in individual cases. Thus, although Act 100's original requirement that county plans conform to Act 100 by January of 1982 was deleted in 1984, it is still arguable that the county plans read together, are

10 Hawail Rev. Stat. 226-52(a)(4) (amended 1984).

17 HaWAII Rev. STAT. 226-52(a)(5) (amended 1984).

18 Hawail Rev. Stat. 226-61(a) (amended 1984).

10 Hawall Rev. Stat. 226-52(a)(5) (amended 1984).

20 The ten functional plans which passed the 1984 legislature by concurrent resolution are: conservation lands, historic preservation, tourism, energy, health, higher education, housing, recreation, cransportation, and water resources development. 
land use plans for the state. Where else will state agencies look for specific guidance on land policy? Neither Act 100 nor the functional plans establish priorities among Act 100's goals, objectives, themes, policies, and guidelines. At least the counties have made such decisions.

The above consistency debate is but one aspect of a large issue that increasingly divides state and county governments: home rule. At bottom, the question of who ultimately controls the use of land in Hawaii depends upon whether the Hawaii Constitution's home rule provisions are broadly or narrowly read. ${ }^{21}$

However, the ability of the counties to exercise their own land controls in the face of conflicting state regulations is made more difficult by the recent Hawaii Supreme Court decision in City and County of Honolulu v. State. ${ }^{22}$ In deciding that the setting of certain county salaries is of statewide concern and so beyond the home-rule authority of the counties which employ those individuals, the court's narrow majority substantially weakens the home-rule article of the state constitution and departs from earlier decisions of the court suggesting a greater role for the counties. The chief justice in his persuasive and well-reasoned dissent rightly observes that "what is at stake in the outcome of the constitutionality of [the pay limit statute] is 'home rule' for the counties." Correctly observing that the court majority has misinterpreted previous case law on home rule in Hawaii, the chief justice characterizes the state attempt to regulate county salaries as "an unconstitutional infringement by the legislature upon the structure and organization of the county governments" which "strikes at the heart of the structure and organization of county governments." 23 It also decides which level of government is going to win in a contest over conflicting land use regulations. In this and other respects, the decision is too broad.

As the foregoing suggests, the counties would prefer that those constitutional provisions be read broadly. However, this might not be entirely to the counties' advantage. In 1978, the U.S. Supreme Court stripped local governments of their traditional immunity from prosecution under national antitrust laws when they conspire to act in "restraint of trade" in various of their governmental activities. Such activities include the awarding of exclusive franchises (stadium concessions, garbage collection contracts, and the like) and zoning land for commercial purposes that favor one landowner/developer over others-or downtown merchants over proposed regional shopping center developers. ${ }^{24}$ The principal exception: when local government was acting pursuant to a clearly articulated state policy, required and supervised by the state. The courts then

\footnotetext{
21 Hawall CONST, art. VII, 2.

22 No. 9459 slip op. (Oct. 17, 1984).

23 Id. at 3 (Lum, C.J., dissenting).

24 City of Lafayette v. Louisiana Power and Light Co., 435 U.S. 389 (1978).
} 
decided in 1982 that a local government's home-rule status-like that of Hawaii's four counties-was not sufficiently statelike to extend state immunity to home-rule local governments. ${ }^{25}$ As a result, local governments throughout the United States are increasingly put to the considerable expense of defending complicated lawsuits, a large percentage of which result from their land use decision-making. The irony for Hawaii's counties is that the more successfully they are able to free their land use decision-making from the state, the less available may be the defense that they are merely enforcing required and supervised state land use policies.

\section{The Relationship of local Plans to Traditional land Use Control ORDINANCES}

Honolulu will probably be the first county to deal with the effect of chartermandated detailed development plans on land use regulations. Honolulu's charter forbids even the initiation of zoning or subdivision amendments that do not conform to the new county development plans. ${ }^{26}$ There has already been one confrontation over whether height limits expressed as "guidelines" in those plans have a different effect from such limits expressed as "standards": Does a proposed 100-foot high building fail the conformance test if the applicable development plan contains a height guideline of fifty feet maximum rather than a standard of fifty feet? Yes, probably so. However, what about a guideline (rather than a standard) of seventy-five feet? Maybe not-but does the extra twentyfive feet make any real difference? There is some question whether the Hawaii Supreme Court is willing to apply any plan guideline so stringently, having in 1981 held a detailed plan ineffective as against a conflicting zoning ordinance because the ordinance adopting it "did not state that the subject therein was zoning." ${ }^{27}$ Of course, few such ordinances do, and the proper reference is to the charter requirements for the relationship of plans to zoning.

This bodes ill as well for efforts to apply any height limit, whether guide or standard, to a building that needs no rezoning to proceed. While courts in other jurisdictions have required existing zoning ordinances to be brought into conformity with new plans (even without specific statutory or charter direction), the Hawaii Supreme Court has never done so. Moreover, currently a 100-foot building could conceivably be built even in a zoning district with a seventyfive-foot limit-with a special or conditional use permit or a variance. These

\footnotetext{
25 Community Communications Inc. v. City of Boulder, 455 U.S. 40 (1982).

28 Honolulu, Hi., Revised Charter of the City and County of Honolulu \$ 5-412(3) (1973).

${ }^{87}$ Nuuanu Neighborhood Ass'n v. Department of Land Utilization, 63 Hawaii 444, 630 P.2d 107 (1981).
} 
devices-all of which have been used ar one time or another to grant substantial relief from bulk zoning requirements like height limitations-are nowhere required to conform to development plans in the Honolulu charter. The charter limits itself to zoning amendments and subdivision changes. Special uses, conditional uses, and variances are neither. Indeed, the permitting of development in special design districts; historic, cultural, and scenic districts; and planned development districts is an administrative action in Honolulu, not a zoning amendment. Therefore, effecting district height "relief' by pointing to lack of conformance with a development plan guideline or standard is likely to be fruitless.

\section{Vested Rights and Development Rights}

If the right to develop land that has been appropriately zoned and planned for development exists at all, then it must be assumed that a development once legally commenced is entitled to completion-that is, the owner's development right has vested. The question is, in this age (and state) of multiple permits, how far along the development continuum must a landowner progress before he has obtained vested rights? The question is usually a judicial one in the absence of state statutes permitting landowners and local governments to "freeze" zoning and other laws for a period of years during which, presumably, a legally permissible development is both commenced and completed. ${ }^{28}$

The vesting of development rights has come before the Hawaii Supreme Court but five times in the past decade, most recently in the Nukolii case. ${ }^{29}$ Whatever the law was before, the Nukolii case puts Hawaii squarely in the camp of states like California, which require a developer to be very far along indeed in the development process to be safe from a change in law that makes it illegal for him to proceed. ${ }^{30}$

The landowners in the Nukolii case had obtained both state and local land use reclassification to zones that permitted resort development. While they were in the process of obtaining other necessary development permits-primarily

38 See C. Siemon, W. Larsen, \& D. Porter, Vested Rights: Balancing Public and Private Development EXPECTATIONs (1982); Hagman, Estoppel and Vesting in the Age of Multi-Use Permits, SW. L.J. 545 (1979).

${ }^{29}$ Graham Beach Partnership v. Save Nukolii Coalition, 65 Hawaii 318, 653 P.2d 766 (1982), cert. denied, 103 S.Ct. 1762 (1984); Life of the Land v. City Council, 61 Hawaii 390, 606 P.2d 866 (1980); Life of the Land v. City Council, 60 Hawaii 446, 592 P.2d 26 (1979); Allen v. City and County of Honolulu, 58 Hawaii 432, 571 P.2d 328 (1977); Denning v. County of Maui, 52 Hawaii 653, 485 P.2d 1048 (1971). See Kudo, Nukolii: Private Development Rights and Public lnterest, 16 URB. LAw. 279 (1984).

so See Callies, Land Use: Herein of Vested Rights, Plans, and the Relationship of Planning and Controls, 2 U. HawaIl L. Rev. 168 (1979). 
shoreland management under local coastal zone regulations-citizen opposition culminated in a referendum petition drive under Kauai's county charter, which permits rezoning of property by referendum provided vested rights are not affected. ${ }^{31}$ The petition requiring the referendum on the county zoning was certified about three months before the permits were granted and about six months before building permits (for condominiums) were issued. Three months after the building permits were issued and construction began-and ten months after the petition was certified-the referendum overwhelmingly overturned the landowners' resort zoning. ${ }^{32}$ Did the landowners have a vested right to proceed?

Not according to the Hawaii Supreme Court. Reversing the court below, the state supreme court held that the certification of a referendum petition automatically creates one more "discretionary" permit (beyond the shoreland permit the developer-landowner already had). Without securing that last discretionary permit, a landowner would proceed entirely at his own risk and no rights to develop would vest. ${ }^{33}$

While originally a victory for direct citizen participation in land use decisions (the developer won a second referendum and has asked for his building permits back), the decision is troublesome for landowners' rights. It is difficult to see how a landowner can rely on any land use development permit short of a building permit where referenda of the Kauai sort are certified, even though certification requires only a percentage of the signatures needed to win a referendum. During the interim between certification and referendum, many laws pertaining to a particular development may change. Even if a landowner wins the referendum and retains his zoning, new and different permits may be necessary before a development can commence. ${ }^{94}$ This actually occurred in California. New shoreland development permits were added to that state's already long list of land development permits just before a landowner obtained his final building permits and had already begun rough-grading and had expended millions of dollars in (legal) reliance on his permits thus far. All for naught: the California courts held he had no vested rights to proceed until that final discretionary permit-not necessary when he began his land development permit applications-was obtained. ${ }^{35}$

This result led California to adopt a developers' agreement law, a course of action that may well presage a similar attempt in Hawaii. ${ }^{36}$ Essentially, such

31 KaUal, Hawail, KaUal County Charter art. V (1969).

32 Graham Beach Partnership, 65 Hawaii 318, 653 P.2d 766 (1982).

ss Id.

st Callies, Nukolii Ruling Cleans Up Numerous Questions, Sunday Honolulu Star-Bulletin and Advertiser, Oct. 17, 1982, at H3, col. 1.

ss Avco Community Developers v. South Coast Regional Comm'n, 17 Cal. 3d 785, 553 P.2d

546, 132 Cal. Rptr. 386 (1976), cert. denied, 429 U.S. 1083 (1976).

${ }^{36}$ CAL. Gov't CODE $\$ 95864-65869.5$ (West 1979). See Holliman, Development Agreements 
statutes permit but don't require local governments to agree with a landowner that all (or certain) of the local land use regulations applicable to a particular parcel will remain as they are (or as modified by the local government) for, say, five years. Thus, any subsequently enacted land use regulation of the kind frozen by the agreement will be inapplicable to the subject property, even if passed by a later-and different-city council. In return, a landowner often agrees to dedicate land or easements, or to build extra infrastructure or other improvements, beyond what a local government could otherwise require as a condition of development permission. Although such an agreement thus binds future legislative bodies in a way normally impermissible under standard local government law, courts in both the United States and England have generally approved these kinds of agreements provided what is bargained away is not too extensive. ${ }^{37}$

How Hawaii ultimately resolves the issue of vested rights may determine the extent to which anything remains of development rights even in properly classified lands. Hawaii may be well along the path to accepting land development as a privilege only, unless some method for fixing vested rights pending final development permission is found-especially in a multi-permit state such as Hawaii.

\section{Land Development in a Multi-Permit State: The Permit Explosion}

According to one study, at least thirty sets of development regulations may apply to a modest shoreland development, even if it is properly classified under the state land use law and zoned for development under county zoning. ${ }^{38}$ The time and effort necessary to obtain development permission is enormous, stifling development both good and bad. Attempts at simplification of the process have been both sporadic and ineffective. ${ }^{39}$

While the problem is not unique to Hawaii, Hawaii does appear to have one of the country's worst cases of "permit explosion." 40 The problem needs to be approached from at least two perspectives: (1) guarantee of development rights

and Vested Rights in California, 13 URB. LAW. 44 (1980). Hawaii rejected such a bill in 1982 and 1984, see Comment, Development Agreement Legislation in Hawaii: An Answer to the Vested Rights Uncertainty, 7 U. HawaII L. ReV. 169 (1985).

s7 E.g., Windsor and Maidenhead Royal Borough Council v. Brandrose Inv., [1981] 3 All E.R. 38 .

38 Policies, Plans and Ordinances as of February 1979, Hawaii Community Development Authority J-3B (1979).

39 Address by Francis Oda, President, American Institute of Architects-Hawaii Chapter, Honolulu City Council Conference on Growth Management (Oct. 1982); F. Bosselman, D. Feurer, \& C. Siemon, The Permit Explosion 7-37 (1976).

10 F. Bosselman, D. Feurer, \& C. Siemon, The Permit Explosion $7-37$ (1976). 
so that the rules are not changed in midstream, and (2) development permission simplification. The first perspective has been discussed above. An agreement between landowner and county would do much to add certainty to the development process. However, some mechanism whereby the state is brought into the process is worth considering. It will profit a landowner very little if Honolulu guarantees that its zoning, subdivision, special management area (SMA), development plans, and other land development regulations will not change for five years with respect to a given parcel, should the state Land Use Commission reclassify the land from urban to conservation, or should the Board of Land and Natural Resources eliminate altogether what little subsidiary development it does permit on urban-adjacent conservation land by means of a rule change.

Simplifying the permit process is a more difficult problem, one that may initially be approachable by one governmental level at a time. A "master permit" might well serve to unite zoning, subdivision, and SMA permits, for example. At the state level, it is worth considering whether, from a permit simplification perspective, drastically reducing or changing the role of the Land Use Commission so that it only considers petitions in which the state has a vital land use interest, would be helpful. ${ }^{41}$ For some projects, especially those jointly commenced by both public and private sectors, negotiated development should perhaps replace existing planning and land use controls altogether.

Whatever is ultimately done, no permit simplification, coordination, or streamlining will be effective unless the multitude of plans under which land use labors is also both coordinated and simplified. As previously noted, $\mathrm{Ha}$ waii's plans at both the state and local level have the force of law and often supersede inconsistent land use regulation of the more traditional sort (such as zoning and subdivision codes). It is therefore critical that any attempt at simplifying Hawaii's land use regulatory process specifically include state and local plans.

\section{State and Local Land Use Policy in a Federal System}

There are some land use regulations about which neither the state nor $\mathrm{Ha}$ waii's four counties can do very much. These are the land use management and control programs imposed as a result of participation in federal programs. Either required by federal law or promulgated in response to a federal grant program, these "federalized" state and local land use controls touch virtually every aspect of state and local land use regulation in Hawaii. ${ }^{22}$ County zoning and subdivi-

11 See, e.g., Daley and Associates, State Land Use Management Study (1981) (unpublished report to the State of Hawaii Department of Planning and Economic Development).

42 A favorite characterization of the late Professor Donald Hagman of the UCLA Law School. 
sion regulations implement both the federal coastal zone management and flood disaster protection acts both in and out of the immediate shoreline areas. ${ }^{43}$ State laws relating to critical areas, especially those enforced by the Board of Land and Natural Resources, are shaped in part in response to the Coastal Zone Management Act. ${ }^{44}$ Indeed, a separate state coastal zone statute is drawn to meet that federal stature's program and implementation requirements. Location of wells, wastewater treatment plants, and accompanying development are guided by the Clean Water Acr. ${ }^{45}$ So is the granting of dredge and fill permits from the U.S. Army Corps of Engineers, which are necessary for any significant shoreland development. ${ }^{46}$ Transportation links and new stationary sources of pollution must meet Clean Air Act pollutant standards and/or fall into air quality zones that are neither too clean nor too dirty. ${ }^{47}$ Any land use that involves the federal government is subject to an environmental impact analysis under the National Environmental Policy Act. ${ }^{48}$

While there is some flexibility in drafting these land use controls, the state has little choice but to adopt something responsive to standards and criteria in these federal laws. Well-intentioned as they are, the federal laws add yet another series of land use regulations that restrict the use of land, a series of regulations that is difficult to coordinate, much less prune or delete.

Of equal concern is the use of federally held land in Hawaii, whether owned outright or, as in the case of ceded lands, held conditionally. State and local land use controls do not extend to federal lands without the permission of the federal government. ${ }^{49}$ Indeed, one of the advantages of state participation in the federal coastal zone management program was the review afforded state and local officials of federal actions affecting the coastal zone that might be inconsistent with a coastal zone management program. ${ }^{60}$ With large and critical areas owned by the federal government, how the federal government uses these lands critically affects land use at their periphery. Indeed, federal land use can so change the character of an area that inconsistent state and local controls on nearby land might be rendered subject to attack in court.

Of equal significance is the disposal of federal lands. A number of proposals

See F. Bosselman, D. Feurer, \& D. Caules, EPA Authority AfFecting land Use (1974).

48 E.g., Honolulu, Hawaii, An Ordinance to Establish the Area and Rules and Regulations For an Interim Shoreline Protection District for Oahu, Ord. 4529 (amended 1977).

44 E.g., 16 U.S.C. 1451-1464 (1972); HaWAII ReV. Stat. $\$ 205 A$ (Supp. 1979).

1533 U.S.C. 1251-1376 (1976).

16 Id.

1742 U.S.C. $\$ 1857$ (1970).

4842 U.S.C. of $4321-4370$ (1969).

49 Kleppe v. New Mexico, 426 U.S. 529 (1976); Ventura County v. Gulf Oil Corp., 601

F.2d 1080 (9th Cir. 1979).

${ }^{50}$ Comment, Federal Consistency Under the Coastal Zone Management Act, 7 U. HAWAII L. REV. 131 (1985). 
in the early 1980s to sell off "surplus" federal lands to help ease the national budget deficit has resulted in considerable adverse comment and concern both nationally and locally. ${ }^{51}$ While the federal government is obligated to return surplus ceded lands to the state, it is under no obligation to give back lands it purchased or condemned. Disposing of these last categories of land to private parties for development would in many instances run directly contrary to state and local land use policy. To the extent they are embodied in land use regulations like Honolulu's development plans, zoning, and subdivision codes and the state's land use law and state plan, such policies would prevent much of the development that would make the land desirable to the private sector in the first place while some of the more strict state and county regulatory policies might be a bit strained legally if enforced against private landowners in an area as highly and densely developed as Waikiki. It hardly follows that the only legally defensible use for such property is a parade of intensely developed highrise projects. The federal government would do better to sell its surplus lands to the state and to Hawaii's counties for open space and other public uses, and at a price far lower than their maximum economic development potential might suggest.

\section{Housing, Development, and Agriculture: A NeEd for Reconciliation}

The conflict between assuring an adequate supply of housing and land use controls directed toward preserving the environment and agricultural land is both real and, if each "virtue" is pushed to its furthest conclusion, irreconcilable. ${ }^{32}$ Land use expert and critic Richard Babcock has observed:

It is not that the poor don't care about environment; it is just that environment to them does not mean keeping the fishing holes free of beer cans or of saving Lake Michigan "for all of us," but of finding decent shelter reasonably accessible to a job. . . . [In Hawaii] [t]hese "preserve" and "improve" restrictions have contributed to one of the nation's most appalling shortages of housing and a substantial increase in the cost of what housing there is. ${ }^{5 s}$

Another commentator has put it more pungently:

Stop growing? But growing is the secret of our success. We have mass affluence, to the extent we have it, not because we took from the rich and gave to the

s1 Shabecoff, Transferring Public Property to Private Control, Honolulu Star-Bulletin, July 13, 1982, at Al1, col. 1 .

52 Babcock and Callies, Ecology and Housing: Virtues in Confict, in Modernizing URban Land Poutcy 205 (M. Clawson ed. 1973).

s3 R. Babcock, Glass Houses and the Law and Other Land Use Fables 149-50 (1977). 
poor but because we became-we grew-so much richer that even most of the poor live tolerably. They still get the short end of the stick, but the stick is so long now that one can get at least a fingerhold on that end... .

[F]or the nation as a whole, for the economy, the conservationist's dichotomy remains, and he has not faced up to it: if we do not stop expanding, we ruin the environment; if we do, we condemn the lower middle classes to their present fate. ${ }^{54}$

The foregoing section has already commented on the regulations governing the development of land. The conclusion is inescapable that the preservation of values upon which many of these controls are based adversely affects the goals set out in Act 100 relating to providing decent housing for all of Hawaii's people.

This is not to imply that either the state or the counties have ignored the problem. Hawaii participates in a variety of programs aimed at alleviating what is an increasing shortfall in affordable housing, even providing for a limited "override" of local land use controls for high-density low- and moderate-income housing projects. ${ }^{65}$ While one might question the wisdom of such a provision from the perspective of sound land use planning (a high-rise is a high-rise regardless of who lives in it, and its appropriateness at any given location from a land use policy perspective should depend upon factors other than who lives in it), it certainly has the potential of moderately expanding the construction of low- and moderate-income housing. Providing shelter, especially for those of limited means, is a social goal of an increasingly critical nature.

But there is also the question of agriculture's future in Hawaii. Preserving agricultural land is by itself a worthwhile goal not only from a statewide perspective; it is important at a national and international level as well. What is not so clear is just how much land should be preserved, and where. Clearly, some undeveloped land is needed for housing. Just as clearly, some of that land-especially around new communities such as Mililani in Central Oahu-may well be prime agricultural land. Yet the state Land Use Commission is directed to encourage urban development in and around existing urban centers. Given the urban infrastructure investment (roads, sewers, water, police/ fire protection, schools, parks) in and around existing developments, this is a sensible goal, but one that may on occasion conflict with policies on agricultural preservation. Yet if the advertised prices for simple, two-bedroom "ohana" units on "owners' land" with all utilities available is any guide, units can be built for sale by the private sector for less than $\$ 40,000$, whether the "average"

s4 Margolis, Our Country 'Tis of Thee, Land of Ecology, 73 EsQuiRE 124 (March 1970).

os E.g., HawaII Rev. Stat. 356-15b (1976) which empowers the Hawaii Housing Authority to develop land at levels and densities unavailable to the private sector. 
citizen would want to live there-or indeed want them "next door" - is not the issue. Simple shelter for a substantial minority of our citizens is. For this-if it is important-some space and beauty compromising may have to be made.

In this connection, renewed interest in land banking should be applauded as a useful tool in preserving agricultural land and other open space as well as potential sites for housing. ${ }^{56}$ By publicly acquiring land or development rights in land the state as owner can decide within the limits of public policy precisely what prime agricultural land should be preserved, regardless of current economic need, and precisely what land should be used for low- and moderateincome housing. It could even write off the land costs for such housing, thereby substantially reducing the cost of housing to the first purchaser and, through restrictive covenants on the land, subsequent purchasers. Indeed, it is only through selective state intervention through purchase of land and rights in land that there is long-term hope of providing for both the housing and agricultural needs of the state.

\section{Regulating Paradise: For WhOM}

In sum, it is possible to bring most development to a screeching halt in Hawaii, given the plethora of land use plans and controls applicable to even the most modest of land use proposals. This would unquestionably result in the preservation of most if not all open space, beaches, agricultural land, historic and cultural sites, views, and other natural and built amenities in the state. It would also result in the exacerbation of the state's housing problem, a major shift in the state's economy, and a considerable reordering of state and local government priorities. Such a far-reaching set of decisions would affect every aspect of life in Hawaii and therefore should be made openly, intentionally, and consciously by the entire Hawaiian community and not accidentally, reactively, and covertly by a particular segment of the broad-based society that makes up today's Hawaii. Conserve and preserve we should and must, or we lose what is uniquely Hawaiian in any and every sense. But provide we must for that use and development of land required for a sophisticated Pacific island state in the last quarter of the twentieth century. Paradise once lost is not easily regained, but paradise preserved, museumlike, by relegating it to the past for the benefit of less than all of its people is neither likely nor laudable. Berter we plan for the development we collectively decide we need and preserve what we collectively decide we want, and agree at the outset that absolute land preservation and

b8 See Onhu Development Conference, Land Banking in Hawall (1973); Callies, Commonwealth of Puerto Rico v. Rosso: Land Banking and the Expanded Concept of Public Use, 2 Mich. J. L. REFORM 199 (1968). 
absolute land development will always conflict absolutely. Only by a judicious mix of the two will we successfully regulate this island paradise. 